\title{
Characteristics of pendent heliconia for use in landscape and as cut flower ${ }^{(1)}$
}

\author{
VIVIAN LOGES(2); CARLOS EDUARDO FERREIRA DE CASTRO(3); \\ ANA CECILIA RIBEIRO DE CASTRO(2); CHARLESTON GONÇALVES ${ }^{(3)}$
}

\begin{abstract}
The Heliconia species with pendent inflorescences and colorful bracts is a good option for landscaping in tropical gardens and cut flowers market. In Brazil only a few species of Heliconia are commercially produced eg. H. rostrata, H. rauliniana and H. chartacea. Aiming to increase the use of outstanding native plants and the knowledge of these products for enthusiasts of tropical flowers, this work was carried out to characterize H. chartacea, H. collinsiana, H. magnifica, H. pendula, H. platystachys, H. pogonantha, $H$. rostrata, $H$. rauliniana and $H$. vellerigera for use in landscaping and as cut flower. The evaluations were performed on plants belonging to the Germplasm Collection of the Instituto Agronômico (IAC), in Ubatuba Unit of Research and Development, located in Ubatuba, São Paulo State, growing in partial shade conditions. Qualitative and quantitative characteristics related to clump and flower stem aspects were analyzed. A point scoring system was used to determine the species most suitable as landscape plant or as cut flower. The plant height range from 2.3 (H. rostrata) to $7.0 \mathrm{~m}$ (H. pogonantha), having inflorescence with vibrant and different colors, varying between yellow, orange, red, pink, green and two color combinations. The inflorescences from most of the species were visible in the clump and remain in good conditions for two (H. platystachys) to five months (H. magnifica, H. rostrata and H. pogonantha) and present six (H. platystachys and H. pendula) to 40 (H. pogonantha) open bracts. White wax in leaves or inflorescences were observed in H. collinsiana, H. chartacea, H. pendula and H. platystachys. On the other hand, H. magnifica, H. rostrata, $H$. pogonantha and $H$. vellerigera exhibit a hairy surface, pubescent to lanuginose. The postharvest durability longer than 10 days was observed only in H. platystachys, H. rostrata, H. chartacea, and H. rauliniana. This characterization and scoring system were important to indicate and diversify heliconia use for landscaping and cut flower.
\end{abstract}

Keywords: selection, cycle, tropical plants, tropical flowers, scoring system.

\section{RESUMO}

Caracterização de helicônias pendentes para uso no paisagismo e como flores de corte As espécies de helicônias com inflorescências pendentes e brácteas coloridas são ótimas opções para o paisagismo em jardins de estilo tropical e também para o mercado de flores de corte. No entanto, apenas $H$. rostrata, H. rauliniana and $H$. chartacea são produzidas comercialmente para este fim no Brasil. Com o objetivo de aumentar o uso e comercialização de plantas nativas e disponibilizar conhecimentos para os apreciadores de flores tropicais, H. chartacea, H. collinsiana, H. magnifica, H. pendula, H. platystachys, $H$. pogonantha, $H$. rostrata, $H$. rauliniana e $H$. vellerigera foram caracterizadas e avaliadas quanto ao potencias de uso no paisagismo e como flores de corte. As avaliações foram conduzidas em plantas da Coleção de Germoplasma do Instituto Agronômico (IAC), Unidade de Pesquisa e Desenvolvimento de Ubatuba, São Paulo, cultivadas a meia sombra. Foram analisados caracteres quantitativos e qualitativos em relação a touceira e haste florais. Foi utilizado sistema de pontuação para determinar a espécie mais adequada para uso no paisagismo e como flores de corte. A altura das plantas variou de 2,3 (H. rostrata) a 7,0 $\mathrm{m}$ (H. pogonantha). As inflorescências, com cores vibrantes e diferenciadas, variaram entre o amarelo, laranja, vermelho, rosa, verde, bem como a combinação dessas cores e apresentaram de seis (H. platystachys e H. pendula) a 40 (H. pogonantha) brácteas abertas. As inflorescências foram facilmente visíveis nas touceiras da maioria das espécies e mantiveram-se atrativas por dois $(H$. platystachys) a cinco meses (H. magnifica, H. rostrata e $H$. pogonantha). Foi observada cerosidade nas folhas e inflorescências de H. collinsiana, H. chartacea, H. pendula e H. platystachys. Por outro lado, H. magnifica, H. rostrata, H. pogonantha e H. vellerigera exibiram pilosidade na superfície, de pubescente a lanuginosa. A durabilidade pós-colheita foi superior a 10 dias apenas em H. platystachys, H. rostrata, H. chartacea e H. rauliniana. A caracterização e o sistema de pontuação foram importantes para indicação e diversificação de espécies de helicônias para o paisagismo e para o mercado de flores de corte.

Palavras chave: seleção, ciclo, plantas tropicais, flores tropicais, sistema de pontuação.

\footnotetext{
(1) Received in 29/08/2016 and accepted in 25/10/2016

(2) Universidade Federal Rural de Pernambuco(UFPE), Recife-PE, Brazil. Corresponding author: vloges@yahoo.com

(3) Instituto Agronômico (IAC), Centro de Horticultura, Campinas-SP, Brazil.

(4) Embrapa Agroindústria Tropical (CNPAT), Fortaleza-CE, Brazil.
} 


\section{INTRODUCTION}

The genus Heliconia, with 182 species, is originated from South America and the neotropical regions. About 37 species were found growing naturally in Brazil (CASTRO et al., 2007). The inflorescences, with different colors as yellow, orange, red or pink, and the wide and long leaves, characterizes it as tropical garden plants.

Heliconia species with pendent inflorescences were easily visible even when in a small number in the clump. The pendent inflorescences, gives movement to the clump, do not permit accumulation of water in the bracts and kept a desirable aspect for more than a month, reducing the clump management. These species are interesting features for landscaping compositions to drift the attention from an undesirable point, hiding walls and as gardens background with the purpose of breaking the effects of monotony (PINHEIRO et al., 2012). Nevertheless, only few Heliconia species with pendent inflorescences such as $H$. rostrata and H. rauliniana are used in landscaping projects in Brazil.

As cut flowers, the agronomic traits expected from a heliconia genotype are: high production of flowering stems throughout the year; short flowering cycle, considering the period from shoot emission to inflorescence harvest; light flowering stems for lower transportation costs; flowering stem longer than $80 \mathrm{~cm}$; easy to handling and packing; and post-harvest durability longer than ten days (LOGES et al., 2012). In northeast region of Brazil, tropical flower growers consider those characteristics and selected the species $H$. rostrata ' 10 days' and $H$. rauliniana to production and stop to cultivate $H$. rostrata '4 days', $H$. chartacea 'Sexy Pink' and 'Sexy Scarlet', H. pendula and H. collinsiana (LOGES et al., 2015).
No water accumulation in the bracts is another important feature of heliconia with pendent inflorescences. This fact consequently reduces organic matter deterioration in the bracts, prevents odors and the occurrence of aquatic insects, which could be observed in species with erect inflorescences (LOGES et al., 2010). These aspects reduce time and cost of cleaning the inflorescences bracts, a necessary postharvest management adopted in H. bihai (OLIVEIRA et al., 2015).

To diversifying the options of tropical plants for landscaping projects and cut flower market, this study was conducted to evaluate ornamental features of nine Heliconia genotypes with pendent inflorescences to be used as ornamental plants and also as cut flowers.

\section{MATERIAL AND METHODS}

The evaluations were performed during three years in clumps from the Heliconia Collection of the Instituto Agronômico (IAC), the Ubatuba Unit of Research and Development, Paraiba Valley Regional Pole of Technology and Development of Agribusiness/APTA, Ubatuba, São Paulo State, in latitude $23^{\circ} 26^{\prime} 02^{\prime \prime} \mathrm{S}$, longitude $45^{\circ} 04^{\prime} 16^{\prime \prime}$ $\mathrm{W}$ and altitude $6 \mathrm{~m}$. The average annual rainfall is 2700 $\mathrm{mm}$. The genotypes were grown in partial sun conditions.

The qualitative and quantitative characteristics were analyzed in clumps of $H$. chartacea, $H$. collinsiana, $H$. magnifica, $H$. pendula, $H$. platystachys, $H$. pogonantha, $H$. rostrata, $H$. rauliniana and $H$. vellerigera (Figure 1$)$.

The potential to landscape and cut flower use included clump and inflorescence traits (Table 1 to 2 ) by methodology modified from Loges et al. $(2007,2012)$ and Pinheiro et al. (2012). 


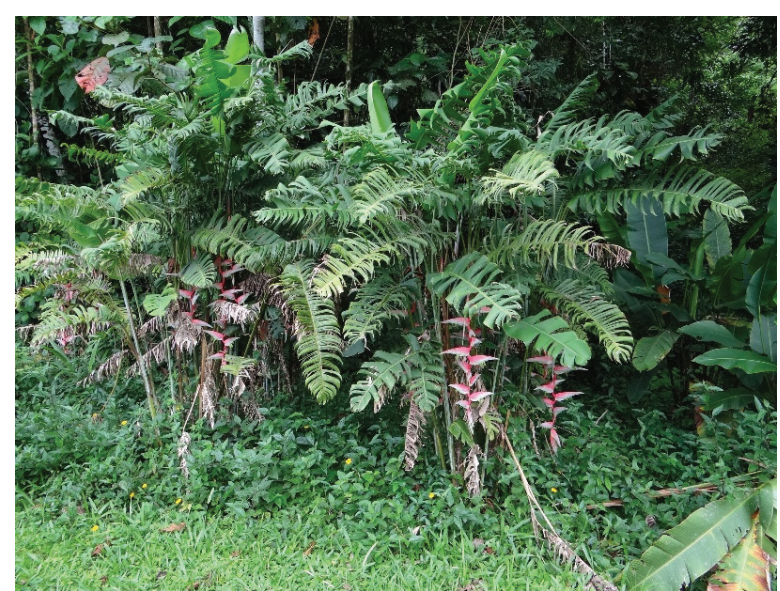

H. chartaceae

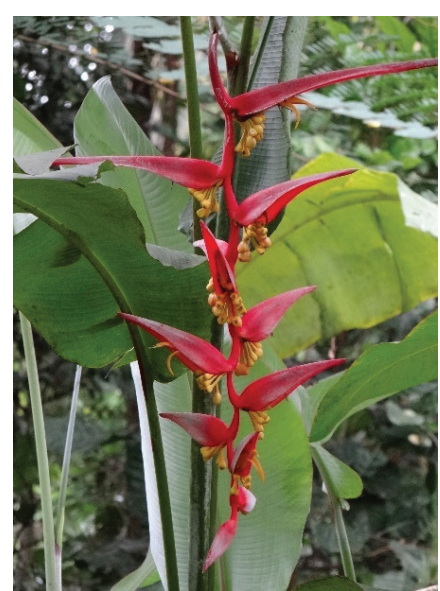

H. collinsiana

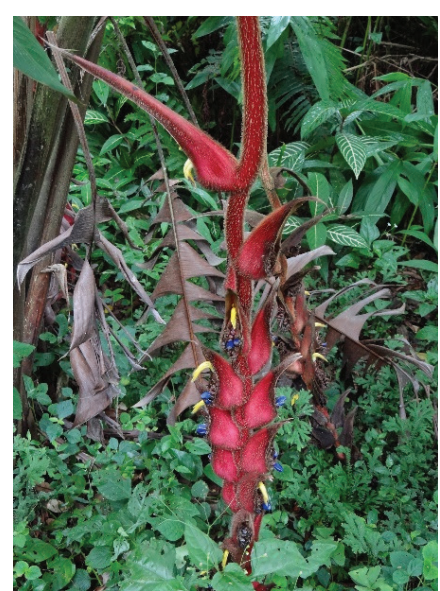

H. magnifica

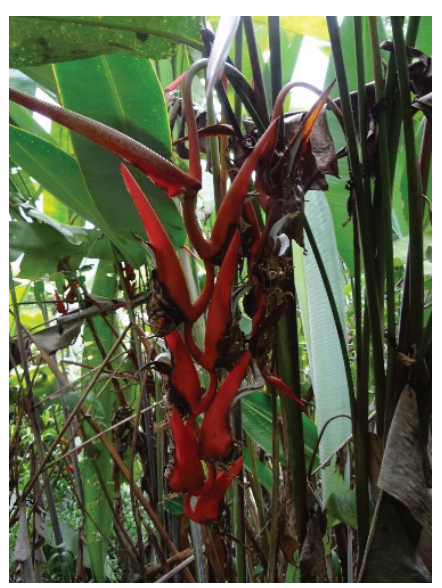

H. pendula

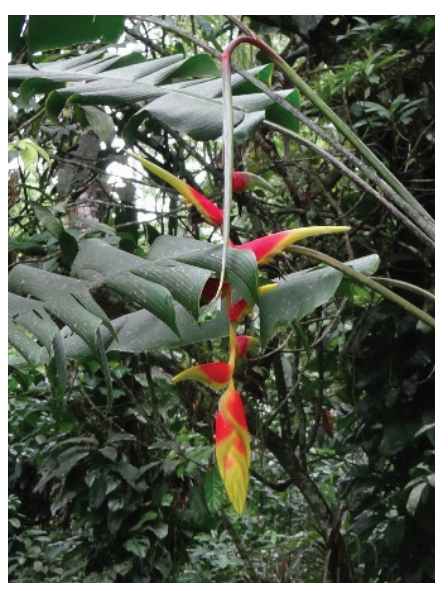

H. platystachys

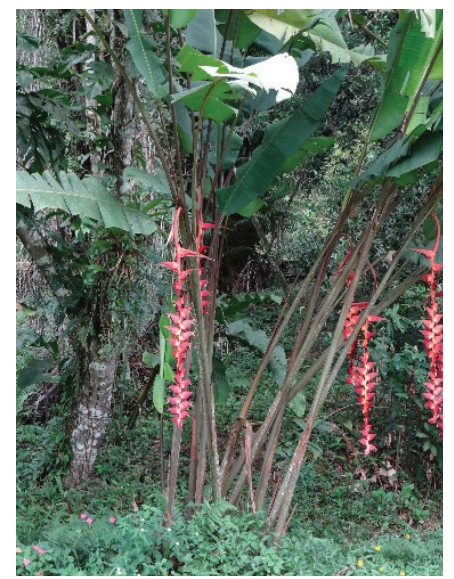

H. pogonantha

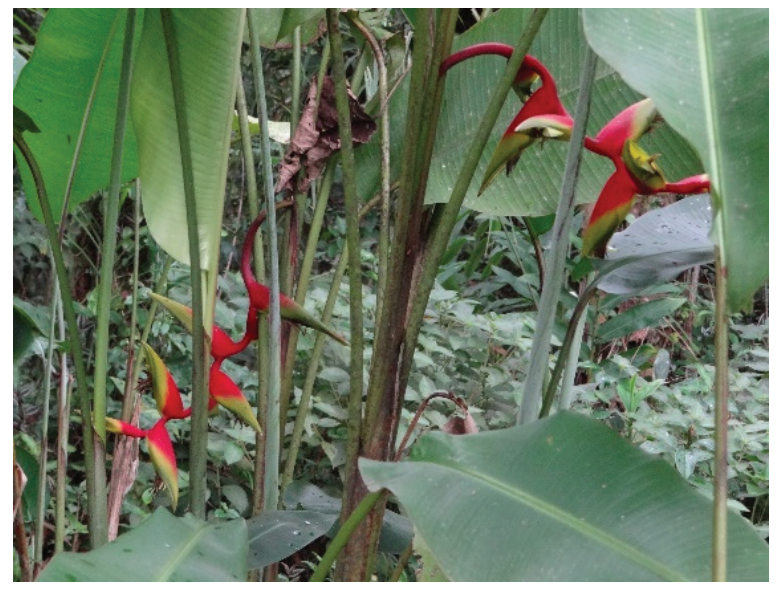

H. rauliniana

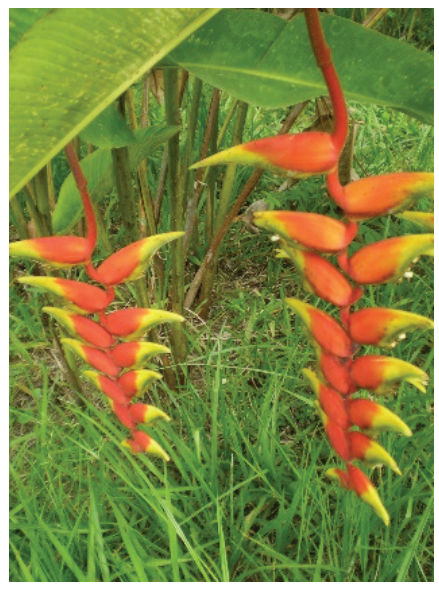

H. rostrata

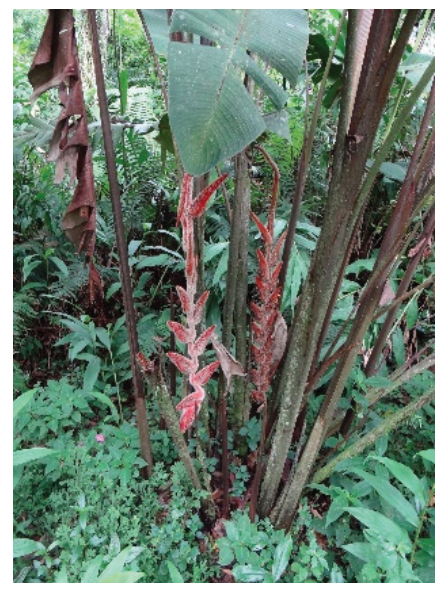

$H$. vellerigera

Figure 1. Heliconia species clumps with pendent inflorescences evaluated from the IAC Collection, São Paulo- Ubatuba, Brazil 
Table 1. Ornamental attributes of clump observed in pendent Heliconia species. IAC Collection, São Paulo- Ubatuba, Brazil.

\begin{tabular}{|c|c|c|c|c|c|c|c|c|c|}
\hline Traits & H. chartaceae & H. collinsiana & H. magnifica & H. pendula & H. platystachys & H. pogonantha & H. rauliniana & H. rostrata & H. vellerigera \\
\hline Commencement flowering & 2 years & 1 to 2 years & $<1$ year & 2 to 3 years & $>2$ years & 2 to 3 years & 1 to 2 years & 1 to 2 years & $>2$ years \\
\hline Flowering period & Nov-Feb & Sep-Feb & all year & Aug-Dec & Dec-Jan & Oct-Feb & Aug-Dec & all year & all year \\
\hline Flowering cycle (months) & 4 & 4 to 5 & 4 to 5 & 3 to 4 & 2 to 3 & 4 to 5 & 3 & 3 to 5 & 4 \\
\hline Clump Height (m) & 3 & 4 to 5 & 4 & 4 & 4.8 & 7 & 3 & 2.3 & 5 \\
\hline Internal shoots & presence & moderate & presence & presence & presence & presence & presence & presence & presence \\
\hline Growth habit & grouped & grouped & grouped & partial & grouped & grouped & grouped & grouped & grouped \\
\hline Clump base area (m) & $1.0 \times 1.0$ & $1.5 \times 1.5$ & $1.0 \times 1.0$ & $2.0 \times 2.0$ & $1.0 \times 1.0$ & $1.5 \times 1.5$ & $0.45 \times 0.5$ & $0.5 \times 0.5$ & $1.5 \times 1.5$ \\
\hline Clump projection area (m) & $2.0 \times 2.0$ & $3.0 \times 3.0$ & $4.0 \times 4.0$ & $2.5 \times 2.5$ & $2 \times 2$ & $4.5 \times 4.5$ & $3.0 \times 3.0$ & $1.0 \times 1.0$ & $3.0 \times 3.0$ \\
\hline Clump maintenance requirements & moderate & moderate & low & high & low & low & low & moderate & moderate \\
\hline Green leaf mass & moderate & moderate & high & moderate & moderate & moderate & high & low & low \\
\hline Number of leave per pseudostem & 5.3 & 5.5 & 4.6 & 4.0 & 6.0 & 5.0 & 4.3 & 6.0 & 5.6 \\
\hline Leaf color & pale green & green & dark green & pale green & green & green & green & dark green & purple ventral side \\
\hline $\begin{array}{l}\text { Wax in the } \\
\text { leaf }\end{array}$ & no & ventral side & no & ventral side & ventral side & no & no & no & no \\
\hline Leaf blade & ripped & not ripped & not ripped & not ripped & ripped & not ripped & not ripped & ripped & not ripped \\
\hline $\begin{array}{l}\text { Stem resistance toe falling } \\
\text { down or break }\end{array}$ & no & no & no & moderate & no & no & yes & no & yes \\
\hline Insect occurrence & no & insects & no & no & no & no & no & no & no \\
\hline Plant diseases & no & no & yes & old leaves & no & no & no & no & old leave \\
\hline
\end{tabular}


A point scoring system was develop to determine the species most suitable as ornamental plants, based on: CFS - Commencement of flowering stage ( 3 points - less than 1 year; 2 points -1 to 2 years; 1 points - more than 2 years); FM - flowering months - months with emission of new inflorescences in the clump ( 3 points - more than 4 months; 2 points 4 to 2 months; 1 point- less than 2 months); FC - Flowering cycle - considering the period from shoot emission to inflorescence harvest ( 3 points - more than 4 months; 2 points -3 to 4 months; 1 points - less than 3 months); CP - clump production (3 points - more than 14 flower stem/clump; 2 points - 14 to 7 inflorescences/ clump; 1 point - less than seven inflorescences/clump); IS - Internal shoots emission (3 points - presence; 2 points - moderate presence; 1 points - absence); CMR - Clump maintenance requirements, considering the necessity to remove old leaves or inflorescences and stem that falling down or break ( 3 points - low; 2 points - moderate; 1 points - high); GLM - Green leaf mass ( 3 points - high; 2 points - moderate; 1 points - low to moderate); IV - Inflorescence visualization ( 3 points - visible; 2 points - partial visible; 1 points - hardly visible); others important ornamental aspects ( 1 point to each of those aspects: different aspects of leaf color; no wax in the leaf or inflorescence; no hair on inflorescences; leaf blade ripped; stem resistance to falling down or break; no insect or plant diseases occurrence). Based on the total point score, the species were considered less suitable (less than 20 points), suitable (20 to 23 points) and very suitable (more than 23 points) to ornamental plants use.

A point scoring system adapted from Castro et al. (2007) was used to determine the species adequacy as cut flowers base on: FM - flowering months - months with emission of new inflorescences in the clump (3 points more than four months; 2 points - four to two months; 1 point - less than two months); CP - clump production (3 points - more than 14 flower stems/clump; 2 points - 14 to 7 inflorescences/clump; 1 point - less than seven inflorescences/clump); SR - stem rigidity (4 points - resistant; 2 points - moderate; 0 points - stem tendency to falling down or break); PD - postharvest durability ( 6 points - more than two weeks; 4 points - one to two weeks; 2 points - less than one week); HA - inflorescence handling aspects (1 point to each of those aspects: one plane bracts arrangement; hair absence in the inflorescence; median to small inflorescence size; light to intermediated flower stem weight; flower persistence in the bracts; slim to intermediate flower stem diameter; median to small flower stem size; presence of bract firmness; bracts imbricate or intermediate imbricate); PF - flower stem packaging facility (1 point to each of those aspects: one plane bracts arrangement; median to small inflorescence size; light to intermediated flower stem weight; slim to intermediate flower stem diameter; presence of bract firmness; bracts imbricate or intermediate imbricate; less than $90^{\circ}$ or more than $110^{\circ}$ bracts angle with the rachi); TA - transport adequacy (1 point to each of those aspects: one plane bracts arrangement; median to small inflorescence size; light to intermediated flower stem weight; hair absence in the inflorescence; slim to intermediate flower stem diameter; presence of bract firmness; less than $90^{\circ}$ or more than $110^{\circ}$ bracts angle with the rachi) and; MV - flower stem market value (3 points - more than U\$2.00/ flower stem; 2 points - U\$2.00 to U\$1.00/flower stem; 1 points - less than U\$1.00/flower stem; 0 points - without market value). One extra point was attributed to species having purple, red and orange bracts colors. Based on the total point score, the species were considered less suitable (less than 25 points), suitable ( 25 to 35 points) and very suitable (more than 35 points) to cut flower use.

\section{RESULTS AND DISCUSSION}

The qualitative and quantitative characteristics related to clump and inflorescence aspects of $H$. chartacea, $H$. collinsiana, $H$. magnifica, $H$. pendula, $H$. platystachys, $H$. pogonantha, $H$. rostrata, $H$. rauliniana and $H$. vellerigera (Table 1 and 2) and the scoring point to determine the most suitable species for landscape (Table 3 ) and cut flower use (Table 4) were recorded and analyzed. 
Table 2. Ornamental attributes of inflorescence from pendent Heliconia species. IAC Collection, São Paulo- Ubatuba, Brazil.

\begin{tabular}{|c|c|c|c|c|c|c|c|c|c|}
\hline Traits & H. chartaceae & H. collinsiana & H. magnifica & H. pendula & H. platystachys & H. pogonantha & H. rauliniana & H. rostrata & H. vellerigera \\
\hline Inflorescence visualization & visible & hardly visible & $\begin{array}{l}\text { partial } \\
\text { visible }\end{array}$ & partial visible & partial visible & visible & partial visible & visible & visible \\
\hline Bracts arrangement & spiraled & spiraled & spiraled & one plane & spiraled & spiraled & spiraled & one plane & one plane \\
\hline Bracts color & pink and green & $\begin{array}{l}\text { dark red to } \\
\text { orange-red }\end{array}$ & $\begin{array}{l}\text { dark red to } \\
\text { maroon }\end{array}$ & bright red & $\begin{array}{l}\text { red and yellow } \\
\text { with green }\end{array}$ & $\begin{array}{l}\text { red with } \\
\text { necrotic lip }\end{array}$ & $\begin{array}{l}\text { red with yellow } \\
\text { green }\end{array}$ & red, yellow and green & red \\
\hline Bracts number & 13 to 15 & 10 to 17 & 13 to 17 & 6 to 8 & 6 to 10 & 40 & 7 to 9 & 8 to 12 & 12 to 18 \\
\hline Hair on inflorescences & absence & absence & presence & absence & absence & presence & absence & presence & presence \\
\hline Wax in the inflorescences & presence & presence & absence & absence & absence & absence & absence & absence & absence \\
\hline Bracts firmness & partial & partial & presence & partial & presence & presence & presence & presence & presence \\
\hline Rachi firmness & presence & presence & presence & presence & presence & presence & presence & presence & presence \\
\hline Flower color and visibility & $\begin{array}{l}\text { Pale green, } \\
\text { visible }\end{array}$ & yellow, visible & $\begin{array}{l}\text { white, } \\
\text { visible }\end{array}$ & white, visible & yellow, visible & $\begin{array}{l}\text { light yellow, } \\
\text { visible }\end{array}$ & $\begin{array}{l}\text { green and white, } \\
\text { visible }\end{array}$ & white, hardly visible & $\begin{array}{l}\text { yellow, hardly } \\
\text { visible }\end{array}$ \\
\hline $\begin{array}{c}\text { Flowers persistence in the } \\
\text { bract }\end{array}$ & no & no & yes & yes & yes & no & yes & no & yes \\
\hline Peduncle length & $10-27 \mathrm{~cm}$ & $8-9 \mathrm{~cm}$ & $50-76 \mathrm{~cm}$ & $20-25 \mathrm{~cm}$ & $12-15 \mathrm{~cm}$ & $12-39 \mathrm{~cm}$ & $18-25 \mathrm{~cm}$ & $26-30 \mathrm{~cm}$ & $19-26 \mathrm{~cm}$ \\
\hline Inflorescence length(m) & $0.8-1.3$ & 0.6 & $1.9-2.0$ & $0.5-0.6$ & 0.5 & $0.7-1.6$ & $0.7-1.0$ & $0.9-1.0$ & $1.0-1.3$ \\
\hline Pseudosteam length (m) & $2.0-2.3$ & $2.5-2.6$ & $2.1-2.2$ & $2.0-1.7$ & 3.2 & $1.8-2.5$ & $1.5-1.9$ & $1.6-2.8$ & $1.6-1.9$ \\
\hline Postharvest durability & 7 to 10 days & 5 days & 5 days & 3 to 5 days & 10 days & 4 to 5 & 10 days & 3 to 10 days & 5 days \\
\hline Flower stem weigh & heavy & heavy & heavy & intermediate & intermediate & heavy & heavy & intermediate & heavy \\
\hline Flower stem diameter & intermediate & thick & thick & slim & intermediate & thick & intermediate & intermediate & thick \\
\hline Bracts angle with the rachi & $100-135^{\circ}$ & $90-100^{\circ}$ & $130-150^{\circ}$ & $30-70^{\circ}$ & $90-95^{\circ}$ & $100-145^{\circ}$ & $15-100^{\circ}$ & $85-120^{\circ}$ & $135-140^{\circ}$ \\
\hline
\end{tabular}


Table 3. Scoring point to determine the pendent Heliconia species most suitable for landscape use. IAC Collection, São Paulo- Ubatuba, Brazil.

\begin{tabular}{|c|c|c|c|c|c|c|c|c|c|c|c|}
\hline & CFS & FP & FC & CP & IS & CMR & GLM & IV & OA & Tot & Ornamental plants use \\
\hline H. chartaceae & 2 & 3 & 3 & 1 & 3 & 2 & 2 & 3 & 4 & 23 & quite suitable \\
\hline H. collinsiana & 2 & 3 & 3 & 3 & 2 & 2 & 2 & 1 & 2 & 20 & quite suitable \\
\hline H. magnifica & 3 & 3 & 3 & 1 & 3 & 3 & 3 & 2 & 3 & 24 & suitable \\
\hline H. pendula & 2 & 3 & 2 & 2 & 3 & 1 & 2 & 2 & 3 & 20 & quite suitable \\
\hline H. platystachys & 1 & 2 & 1 & 1 & 3 & 3 & 2 & 2 & 5 & 20 & quite suitable \\
\hline H. pogonantha & 1 & 3 & 3 & 2 & 3 & 3 & 2 & 3 & 4 & 24 & suitable \\
\hline H. rauliniana & 2 & 3 & 2 & 2 & 3 & 3 & 3 & 3 & 6 & 27 & suitable \\
\hline H. rostrata & 2 & 3 & 3 & 2 & 3 & 2 & 1 & 3 & 5 & 24 & suitable \\
\hline H. vellerigera & 1 & 3 & 3 & 1 & 3 & 2 & 1 & 3 & 5 & 22 & quite suitable \\
\hline
\end{tabular}

CFS - Commencement of flowering stage; FP - Flowering period; FC - Flowering cycle; CP - Clump production; IS - Internal shoots; CMR - Clump maintenance requirements; GLM - Green leaf mass; IV - Inflorescence visualization; OA - ornamental aspects.

The clumps of $H$. chartacea, with $3 \mathrm{~m}$ height, demonstrated grouped growth habit with internal shoots. The leaves are pale green, ripped and without wax. The flowering month period was from November to February and flowering cycle lasted for 4 months. The inflorescence presents 13 to 15 pink and green colored bracts, easily visible in the clump. After three or more open bracts, the bracts arrangement became spiraled and the inflorescence present several planes, enabling a more interesting visualization for the landscape use.

Table 4. Scoring point to determine the pendent Heliconia species most suitable for use as cut flowers. IAC Collection, São Paulo- Ubatuba, Brazil.

\begin{tabular}{|c|c|c|c|c|c|c|c|c|c|c|}
\hline & FP & CP & SR & PD & HA & PK & TA & MV & Tot & Cut flowers use \\
\hline H. chartaceae & 3 & 1 & 4 & 6 & 5 & 4 & 4 & 3 & 30 & quite suitable \\
\hline H. collinsiana & 3 & 3 & 4 & 2 & 3 & 1 & 1 & 2 & 19 & fairly suitable \\
\hline H. magnifica & 3 & 1 & 4 & 4 & 3 & 4 & 3 & 3 & 25 & quite suitable \\
\hline H. pendula & 3 & 2 & 2 & 2 & 5 & 4 & 4 & 1 & 23 & fairly suitable \\
\hline H. platystachys & 2 & 1 & 4 & 4 & 7 & 5 & 5 & 3 & 31 & quite suitable \\
\hline H. pogonantha & 3 & 2 & 4 & 4 & 3 & 2 & 3 & 3 & 24 & fairly suitable \\
\hline H. rauliniana & 3 & 2 & 4 & 6 & 4 & 2 & 3 & 3 & 27 & quite suitable \\
\hline H. rostrata & 3 & 2 & 4 & 6 & 5 & 5 & 4 & 2 & 31 & quite suitable \\
\hline H. vellerigera & 3 & 1 & 4 & 4 & 2 & 2 & 2 & 3 & 21 & fairly suitable \\
\hline
\end{tabular}

FP - flowering period; CP - clump production; SR - stem rigidity; PD - postharvest; HA - flower stem and inflorescence handling; PF - flower stem packaging; TA - transport adequacy one plane bracts arrangement; MV - flower stem market value

Due to the weight of the inflorescences, some plants fall or break, requiring support. The cultivation of this species along to the passers-by access areas is not recommended because of the wax presence in the inflorescences. The postharvest durability was of the flower stem was, at least, 10 days. Based on the total point score, H. chartacea were considered suitable both as ornamental plant (23 points) and cut flower use (30 points). Nevertheless, in some regions of Brazil, $H$. chartacea 'Sexy Pink' and 'Sexy Scarlet' were difficult to cultivate, because of low production and low market acceptance due to the big size ( 0.8 to $1.3 \mathrm{~m}$ inflorescence length) and weight of the flower stem. Despite the high ornamental appeal, producers may not cultivate this species for these reasons (LOGES et al., 2015).
The leaves of $H$. collinsiana are green with wax in the abaxial side. The inflorescences are hardly visible in the clump. The 10 to 17 bracts colors could be dark red to orange-red. The moderate occurrence of internal shoots in the clump and following down tendency could compromise the aesthetic of the clump and makes it suitable plant for landscape use (20 points). The partial bracts and rachi firmness, spiraled arrangement of the bracts, presence of wax associated with the short inflorescence postharvest durability ( 5 days), influence the low score point (19 points - less suitable) and limited the use of this species as cut flower.

H. magnifica, as the name mention, is very suitable as ornamental plants for landscaping projects ( 24 points). The clump is grouped with beautiful, big and dark green 
leaves with $4 \mathrm{~m}$ height. The clump basal area measures about $1.0 \times 1.0$ and its projection $4.0 \times 4.0 \mathrm{~m}$. The spiraled inflorescences with about $2.0 \mathrm{~m}$ length shows 17 dark red colored lanuginose bracts partial visible in the clump. The blue fruits and white flowers contrast in the bracts. Nevertheless, those characteristics associated with the heavy flower stem weight and low postharvest durability make this specie suitable for the use as cut flower (25 points).

The $H$. pendula clumps could have $4 \mathrm{~m}$ height, grouped growth habit with internal shoots. The leaves are pale green, with wax in the ventral side. The flowering month period was from August to December and flowering cycle lasted 3 to 4 months. The inflorescence with 6 to 8 bright red bracts are partial visible in the clump. It makes this species suitable as ornamental plants for landscape use. The inflorescence is in one plane, the rachis is not spiraled, the bracts colors are bright red, nevertheless the bracts are partial firm, similar to $H$. collinsiana. H. pendula was considered less suitable (23 points) to be used as cut flower. It was observed that in northeast region of Brazil, this species was difficult to cultivate, shows low production and low market acceptance (LOGES et al., 2015).

H. platystachys has clump height of approximately 4.8 $\mathrm{m}$ and demonstrated grouped growth habit with internal shoots. The leaves are green, ripped, waxy at the ventral side. The flowering month period was from December to January and the flowering cycle lasts only 2 to 3 months. The inflorescences exhibit 6 to 10 bracts and is partial visible in the clump. This species is suitable for landscape (20 points), because of its colorful bracts, a mix of red, yellow and green and its spiral arrangement providing motion aspect to the clump. Some plants fall or break, requiring support. The postharvest durability is at least 10 days. Based on the total point score, this specie was considered suitable (31 points) to use as cut flower, nevertheless the size and angle of the bracts could limit the packing and the market acceptance.

The characteristics observed in $H$. pogonantha indicated that it is a very suitable species to be use as an ornamental plant (24 points). Vigorous clump with $7 \mathrm{~m}$ height, is one of the taller species of Heliconiaceae family. Despite the inflorescences with 0.7 to $1.6 \mathrm{~m}$, the plants demonstrated moderate falling down tendency. The grouped growth habit and the internal shoot presence in clump provites a moderate green mass that can be use to big open spaces and architectural compositions. The dark red inflorescence with spirale bracts arrangement are easily visible and contrast with the dark green leaves. The flowering month period was from October to February and flowering cycle lasts more than five months. The inflorescence could have 40 open lanuginous bracts. Nevertheless, the size of the flower stem and the necrotic lip of the bracts (turns to black in 4 to 5 days) categorize it as less suitable (24 points) to use as cut flower.

The $H$. rauliniana inflorescence production occurs for a period of approximately from August to December, with a flower cycle of 3 months. The clump height was $3 \mathrm{~m}$, with clump base area of $0.45 \times 0.5 \mathrm{~m}$ and the projection area of $3.0 \times 3.0 \mathrm{~m}$, requiring large spaces to grow. The shoots grow in the internal part of the clump and the growth habit is grouped. The plants present green leaves that contrast the red with yellow green pendent spiraled inflorescences with 7 to 9 bracts that is partially visible on the clump. The inflorescences kept the visual quality in the clump for more than two months after its emergence and the plant don't have tendency to falling down, requiring low maintenance. Those characteristics makes this specie very suitable to use as ornamental plant (27 points). As cut flower, its normally harvest with two open bracts since with more than three open bracts the inflorescence became spiraled. The cut flower stem maintains the postharvest quality for 10 days and based on the total point score, the species was found suitable (27 points) to use as cut flower.

H. rostrata exhibit grouped clumps with $2.3 \mathrm{~m}$ height. The inflorescences present white flowers that contrast with the red, yellow and green bracts and easily visible. The pubescent bracts could increase dust accumulation. The inflorescence could present 8 to 12 opened bracts, on a single plane, and showed the desirable aspects for landscaping for more than three months, that is why is suitable to use this species of Heliconia in landscaping (24 points - very suitable). As cut flower, the inflorescence postharvest durability varies 3 to 10 days, depending of the genotype. The 31 points score of the species classified it as suitable for use as cut flower. The cut flowers growers selected the $H$. rostrata ' 10 days' since it present high postharvest durability, produced round the year, low maintenance requirement and was found easy to package.

$H$. vellerigera species has red inflorescences, with 12 to 18 open lanuginous bracts in one plane. It takes more than two years to commence flowering, however flowering cycle is more than four months. The clump measure $5 \mathrm{~m}$ height and present green leaves at the dorsal side and purple at ventral side, contrasting with the red inflorescence. The grouped growth habit and the presence of internal shoots creates a moderate green mass proper to large open spaces. Those characteristics indicates that this specie is suitable for ornamental plant use (22 points). The low durability and size of the inflorescence, about $1.3 \mathrm{~m}$, makes it difficult to use as cut flower and contribute to the low score points (21 points - less suitable).

All the evaluated genotypes showed suitability to be used in landscape projects considering plants vigor, uniform distribution of the plants in the clumps, low maintenance, visible inflorescences for a long flowering period and long lasting inflorescences for more than one month. To use as cut flowers, only $H$. chartacea, $H$. platystachys, $H$. rostrata and $H$. rauliniana were considered suitable.

\section{ACKNOWLEDGMENTS}

The authors would like to thanks to CAPES (Coordination of University Level Students Improvement, CNPq (National Development Council), FACEPE (Fundação de Amparo à Ciência e Tecnologia de Pernambuco) for their financial support and to Daniela Merida for technical assistance with experiments. 


\section{REFERENCES}

CASTRO, C.E.F.; MAY, A.; GONÇALVES, C. Espécie de helicônia como flor de corte. Revista Brasileira de Horticultura Ornamental, v.12, n.2, p.87-92, 2007.

LOGES, V.; CASTRO, A.C.R.; COSTA, A.S.; GUIMARÃES, W.N.R.; CASTRO, M.F.A.; NOGUEIRA, L.C. Ornamental attributes of heliconia plants for landscape design in Brazil. Acta Horticulturae, v.743, p.75-80, 2007.

LOGES, V.; CASTRO, C.E.F.; GUIMARÃES, W.N.R.; COSTA, A.S.; LIMA, T.L. DE A.; LEITE, K.P. Agronomic traits of Heliconia for cut flowers use and molecular markers. Acta Horticulturae, v.937: 535-543, 2012.

LOGES, V.; SILVA, F.A.; OLIVEIRA, T.R.S; GUIMARÃES, W.N.R.; CASTRO, A.C.R.; CASTRO, M.F.A. Insects associated to Heliconia spp. inflorescences used as ornamental plants. Acta Horticulturae, v.881, p.595-598, 2010.
LOGES, V.; TEXEIRA, M.C.F.; SILVA, S.S.L.; LAGO, P.G.P.; SILVA, S.Á.C.G. DA; LIMA, T.L. DEA.; CASTRO, A.C.R. DE. On farm heliconia cut flower selection in Pernambuco - Brazil. Acta Horticulturae, v.1104, p.455462, 2015.

OLIVEIRA, T.R.S.; COSTA, E.K.S.L.; CÂMARA, C.A.G.; LOGES, V. Postharvest durability of Heliconia bihai flower stem treaded with essential oils to insect control. Acta Horticulturae, 1060, p.229-234, 2015.

PINHEIRO, P.G.L.; LEITE, K.P.; LIRA JUNIOR, M.A.; LOGES, V.; CASTRO, M.F.A. Heliconia characteristics for landscape use. Acta Horticulturae, v.953, p.293-298, 2012. 